Pesq. Vet. Bras. 35(3):265-269, março 2015 DOI: $10.1590 / \mathrm{S} 0100-736 \mathrm{X} 2015000300009$

\title{
Reproductive efficiency of asymptomatic Theileria equi carriers mares submitted to an embryo transfer program $^{1}$
}

\author{
Luciana L. Bezerra ${ }^{2 *}$, Júlio C.F. Jacob², Huarrisson A. Santos ${ }^{3}$, Carlos L. Massard ${ }^{3}$, \\ Paula C.A. Silva ${ }^{2}$, Fabrício N. Gaudêncio ${ }^{3}$ and Marcus A.F. Sá ${ }^{2}$
}

\begin{abstract}
Bezerra L.L., Jacob J.C.F., Santos H.A., Massard C.L., Silva P.C.A., Gaudêncio F.N. \& Sá M.A.F. 2015. Reproductive efficiency of asymptomatic Theileria equi carriers mares submitted to an embryo transfer program. Pesquisa Veterinária Brasileira 35(3): 265-269. Departamento de Reprodução e Avaliação Animal, Departamento de Parasitologia Animal, Universidade Federal Rural do Rio de Janeiro, Seropédica, RJ 23890-000, Brazil. Email: luluzootec@uol.com.br

This study aimed to assess and evaluate the effects of Theileria equi infection on embryonic recovery, gestation and early embryonic loss. Thirteen Mangalarga Marchador Theileria equi positive donors (diagnosed through nested-PCR) and 40 embryos receptors were used. Donors were submitted to two embryo collections in two consecutive estrous cycles (GId); after, the same mares were treated with imidocarb dipropionate $(1.2 \mathrm{mg} / \mathrm{kg}$ IM.) in order to collect more embryos in two more estrous cycles (GIId). Receptors were divided into two groups (control and with treated) with 20 animals each, where one group was the control (GIr) and the other one (GIIr) treated with $1.2 \mathrm{mg} / \mathrm{kg}$ IM of imidocarb dipropionate assessing the gestation rate at 15, 30, 45 and 60 days. After 52 embryo collections, the embryonic recovery rates were $53.84 \%(14 / 26)$ and $65.38 \%(17 / 26)(p>0.05)$ for GId and GIId, respectively. The gestation rate was 70\% (14/20) (p>0.05) at 15, 30, 45 and 60 days in group GIr and for GIIr was 85\% (17/20) (p>0.05) at 15 days, 80\% (16/20) $(p>0.05)$ at 30,45 and 60 days. The treatment with imidocarb dipropionate did not cause significant improvement in the reproductive efficiency at an ET program.
\end{abstract}

INDEX TERMS: Theileria equi, babesiosis, biotechnology, nPCR, mares.

RESUMO.- [Eficiência reprodutiva de éguas portadoras assintomáticas de Theileira equi submetidas a um programa de transferência de embriões.] Este estudo teve por objetivo avaliar a influência da infecção por Theileria equi nas taxas de recuperação embrionária, gestação e perda embrionária precoce. Foram utilizadas 13 doadoras e 40 receptoras de embrião da raça Mangalarga Marchador, positivas para Theileria equi através da técnica de nested-PCR. Nas doadoras foram realizados duas coletas de embriões em dois ciclos estrais consecutivos (GId), em sequência, esses mesmos animais foram tratados com dipropionato de imidocarb (1,2mg/kg IM.) para realização de mais duas coletas de

\footnotetext{
${ }^{1}$ Received on October 18, 2014.

Accepted for publication on March 28, 2015.

${ }^{2}$ Departamento de Reprodução e Avaliação Animal, Departamento de Parasitologia Animal, Universidade Federal Rural do Rio de Janeiro (UFRRJ), Campus de Seropédica, BR-465 Km 7, Seropédica, RJ 23897-970, Brazil. *Corresponding author: luluzootec@uol.com.br

${ }^{3}$ Departamento de Parasitologia Animal, UFRRJ, Campus de Seropédica, BR-465 Km 7, Seropédica, RJ 23890-000.
}

embriões em dois ciclos estrais (GIId). As receptoras foram divididas em dois grupos de 20 animais cada, onde um grupo foi o controle (GIr) e, o outro grupo, foi tratado (GIIr) com $1,2 \mathrm{mg} / \mathrm{Kg}$ IM de dipropionato de imidocarb, com intuito de avaliar a taxa de gestação aos 15, 30, 45 e 60 dias. Após a realização de 52 coletas de embrião, as taxas de recuperação embrionária foram de 53,84\% (14/26) e 65,38\% (17/26) ( $p>0,05)$ para GId e GIId, respectivamente. A taxa de gestação foi de 70\% (14/20) (p>0,05) aos 15, 30, 45 e 60 dias no grupo GIr e para o GIIr foi 85\% (17/20) (p>0,05) aos 15 dias, $80 \%(16 / 20)(p>0,05)$ aos 30,45 e 60 dias. 0 tratamento com dipropionato de imidocarb não promoveu melhora significativa na eficiência reprodutiva em um programa de TE.

TERMOS DE INDEXAÇÃO: Theileria equi, babesiose, biotechnologia, nPCR, éguas.

\section{INTRODUCTION}

The success of embryo transfer programs (ET) in equines can be affected by several known factors such as animal 
body score, uterine status, day of embryo collection, quality and handling of the embryo, besides requirement of highly specialized workers. However, there are also some unknown factors that could interfere in the ET. Animals free of diseases, ectoparasites and endoparasites are necessary for an ideal embryo transfer program; however, due to Brazilian tropical climate and the lack of sanitary control, it is difficult obtaining animals free of some parasitosis, such as babesiosis.

The demand for assisted reproduction techniques development in equideoculture has considerably increased . Brazil is one of the leading countries in the use of Embryo transfer (ET), along with the USA and Argentina. Although ET use has increased over the last decades, its numbers have fluctuated along with the financial health of the equine industry. Due to the high cost of the technique it has only been used in genetically superior animals as donors (Squires et al. 1999).

The babesiosis has been described as the main equine parasitosis, due to direct damages such as reduced performance and mortality, besides the indirect damages as commercialization restraint and specially exports (Friedhoff 1990). The mortality in infections by Theileria equi is low; in general the animals recover from the disease acute phase and of remaining parasite asymptomatic carriers. During the infection chronic phase, unspecified clinical signs, as impatience, weight loss and reduced physical and reproductive performance are common (Schein 1988).

Cases of congenital babesiosis have been observed, suggesting transplacental transmission (Santos et al. 2008), at the first trimester of gestation (Allsopp et al. 2007), besides the occurrence of aborted fetuses with jaundice and anemia, premature or born sick foals, showing symptoms as anemia, prostration, jaundice and reluctance to feed (Du Plessis \& Basson 1966). Thus, considering the small number of embryos obtained per mare a year, a better pregnancy rate and lower embryonic loss are required. Accordingly, it is important assessing the influence of T. equi infection on embryonic recovery rates, gestation and early embryonic loss in a Commercial Program of Equine Embryo Transfer.

\section{MATERIALS AND METHODS}

The present study took place in a Commercial Center for Embryo Transfer, located in the city of Itaguaí, and on two stud farms in the city of Seropédica/RJ, Brazil. Thirteen donors and 40 receptors of embryos from the "Mangalarga Marchador" breed were used. The animals were between 3 and 10 years old, presented body score between four and five (NRC 2007) and were previously examined for T. equi by the nested-PCR method (Nicolaiewsky et al. 2001) at the Laboratory of Hematoparasites and Vectors of the Federal Rural University of Rio de Janeiro.

During the whole study period, the control of endoparasites was performed through the association of $1,2 \mathrm{~g}$ ivermectin and $15,0 \mathrm{~g}$ praziquantel, and the ectoparasites control were accessed by a weekly cypermethrin $15 \%$ pulverization. The embryo donor mares were kept in individual stalls, fed with four quilograms of commercial feed per day with $13 \%$ of protein, alfalfa hay, commercial mineral salt and water ad libtum. The embryo receptor mares were kept in pickets, being fed in troughs with two kilos of commercial feed per day with $13 \%$ protein, alfalfa hay, mineral salt and water ad libtum.
The blood samples were collected from a puncture in the jugular vein, with $40 \times 12$ needles, placed on flasks with ethylenediaminetetraacetic acid 11\% (EDTA) anticoagulant and sent in isothermal boxes to the Laboratory of Experimental Chemotherapy in Veterinary Therapy of the Federal Rural University of Rio de Janeiro. To access the hematimetry and leucometry a Poch 100 IV Roche electronic equipment was used. The differential leukocytes count was performed by stained blood smears and the total solids determination was accessed through refractometry.

For the reproductive test, the mares were every two days examined by transrectalpalpation and ultrasonography until they presented about $30 \mathrm{~mm}$ diameter follicle, when they began to be daily examined. When the largest follicle reached $\geq 35 \mathrm{~mm}$ diameter and uterine echogenicity suitable with estrus, ovulation was induced with 1000 UI of intravenous human chorionic gonadotropin (hCG). The Artificial Insemination (AI) was performed with fresh semen of assured quality 24 hours after the hCG administration. Whether there was no ovulation 48 hours after the AI, mares would be submitted to the same procedure. The dose of 500x106progressively motile spermatozoa was used to inseminate the mares. Seven and nine days post-ovulation (D7 and D9), embryo recovery attempt was performed in the donor mares (Fleury et al. 2001) at two consecutive estrous cycles (GId). After, these same animals were treated with imidocarb dipropionate $(1.2 \mathrm{mg} / \mathrm{kg}$ IM monthly) for two more embryos in two estrous cycles (GIId). Embryo receptors were divided into two groups of 20 animals each, where one was the control (GIr) and, the other one treated with (GIIr) imidocarb dipropionate. The receptors were then inovulated with a synchronicity degree from -1 to +5 (ovulation one day before, up to five days after the donors), and then the gestation rates were evaluated at 15,30 , 45 and 60 days.

The hematological parameters were transformed (natural $\log$ ) and submitted to the t test ( $p>0.05$ ) and the embryonic recovery rates, gestation and animals embryo quality were assessed by chi-square test with $5 \%$ significance level and $95 \%$ interval according to Sampaio, 2002.

\section{RESULTS}

In the present study, as the 13 embryo donors as the 40 receptors presented positive result for T. equi based on the nested-PCR diagnostic method at the beginning of the procedures. At the end of the experiments, after imidocarb dipropionate treatment, $69 \%(9 / 13)$ of embryo donors and $50 \%(10 / 20)$ of embryo receptors presented negative results for T. equi in the nPCR (Table 1 and 2). The receptors untreated group of receptors presented $20 \%(4 / 20)$ of negative animals, using the same diagnostic method (Table 2).

Donor and receptor mares presented normal erythrogram before and after treatment with imidocarb dipropionate. Regarding the leukogram, the embryo donors presented a decrease in leucocytes and total neutrophil, and a slight increase of lymphocytes and monocytes after treatment. The embryo receptors presented a blood count within normal parameters.

Before donor mares have been treated with imidocarb dipropionate, the embryonic recovery rate was 53.8\% $(14 / 26)$. After the treatment, the recovery rate increased to $65.9 \%(17 / 26)$. Even with this numerical superiority observed after treatment, the chi-square test did not show significative difference ( $p>0.05)$.

The gestation rate at $15,30,45$ and 60 days in the un- 
Table 1. DNA detection of Theileria equi by the nested PCR technique in embryo donor mares before and after treatment with imidocarb dipropionate

DNA detection of Theileria equi by Nested-PCR in embryo donors

\begin{tabular}{lcc}
\hline Donors & Positives & Negatives \\
Before treatment & $13(100 \%)$ & 0 \\
After treatment & $4(31 \%)$ & $9(69 \%)$
\end{tabular}

Table 2. DNA detection of Theileria equi by the nested PCR technique in embryo receptor mares not treated and treated with imidocarb dipropionate

\begin{tabular}{lccccc}
\multicolumn{2}{c}{ DNA detection of Theileria equi by Nested PCR in embryo receptors } \\
\cline { 2 - 3 } \cline { 5 - 6 } Receptors & \multicolumn{2}{c}{ Not treated } & & \multicolumn{2}{c}{ Treated } \\
\hline Begitives & Negatives & & Positives & Negatives \\
End of experiment & $16(80 \%)$ & $4(20 \%)$ & & $10(50 \%)$ & $10(50 \%)$
\end{tabular}

treated receptor group was $70 \%(14 / 20)$ with no embryonic loss. In the treated group the gestation rate at 15 days was $85 \%(17 / 20)$ and at 30,45 and 60 days it was $80 \%$ $(16 / 20)$, considering there was embryonic loss at 30 days of gestation in one of the treated mares. No significative difference $(\mathrm{P}>0.05)$ was observed among the gestation rates.

The treatment with imidocarb dipropionate caused improvement on the quality of the recovered blastocysts. Before treatment, it was obtained $71.43 \%$ of embryos (10/14) classified as grade I. After treatment the number of grade I embryos was $94.12 \%(16 / 17)$. An increase of $22.69 \%$ in the quality of grade I embryos was observed. The percentage of embryos classified as grade II before treatment was $28.57 \%(4 / 14)$ and after treatment was 5.88\% (1/17). No significative difference was observed $(p>0.05)$ among the results after the chi-square test.

\section{DISCUSSION}

Aiming to characterize the occurrence of Theileria equi, several researches have being performed in Brazil. Serological tests have been in epidemiological studies, showing the presence of antibodies and indicating, therefore, that these animals were in contact with the parasite in some moment of their lives. The greatest obstacle of these serological techniques lies in the fact that the antibodies can remain circulating for months or even for the entire life of the animals, characterizing positivity in serological tests. For asymptomatic carriers, the molecular tests are more indicated, since they are able to detect the presence of blood circulating protozoa at low rates. The nPCR has been cited as the best technique due to its amplification reactions, which ensures greater sensitivity to the technique (Baldani 2004). The highest percentage of negative animals in the treated donors and receptors groups is probably due to the prophylactic treatment with imidocarb dipropionate. It is believed that, once animals did not present any symptomatology, the parasitemia was already low, even when still detectable; and after treatment the parasitemia level became lower and probably undetectable by the method. The nPCR method based on the gene sequence ema-1 of T. equi, is able to detect parasitemias up to $0.000006 \%$, the equivalent of 5 infected cells from a total of $10^{8}$ erythrocytes (Nicolaiewsky et al. 2001). In another evaluation of this PCR technique for T. equi routine detection (Rampersad et al. 2003) through blood samples analyses from healthy and clinically sick sick equines, the nPCR method was able to detect the parasite 3.6 times over than stained blood smears and 2.2 times over than the detection at the first PCR amplification, showing higher sensitivity when compared to the conventional parasitiological methods. The negative results obtained with no treatment receptors at the end of the experiment have possibly been associated to the reduction in the parasitemia levels due to a better handling of these animals during mating season, reducing the contact with the vector tick and possible reinfections.

The treatment with imidocarb dipropionate in infected equines has demonstrated that this compound causes parasite eradication from blood; however, according to Bruning (1996) the horses remained always infected. Clinically infected animals receiving imidocarb dipropionate $(5 \mathrm{mg} /$ $\mathrm{kg}$ ) treatment presented parasitemia presented decrease after two days, from $20 \%$ to $10 \%$ of infected erythrocytes and untreated ponies presented an increase from 20 to $60 \%$ in three days (Simpson \& Neal 1980).

During the chronic phase there is no significative alteration between uninfected equines hematocrit T. equi carries (Hailat et al. 1997). According to that author, the infected equines and those ones previously treated with imidocarb dipropionate did not present any clinical sign of the disease. The same authors still repported equines highly infected presenting a reduction in their hematocrit from around 20 to $30 \%$ (Hailat et al. 1997).

According to Schein (1988), equines infected by T. equi develop a solid immunity protecting them against clinical diseases in cases of re-exposure to the parasite. This protection has been attributed to a continuous stimulation of the immune system by parasites persisting in the organism during the chronic phase of the disease, even with low parasitemia rates. According to Bruning (1996) imidocarb dipropionate treatment to T. equi has proven removing the parasite from blood circulation, although, the infected equines have remained carriers through out their lives , being responsible for the propagation and maintenance of infection.

According to the study performed by Squires et al. (2003) the embryonic recovery rate was between 50 and $75 \%$. Some studies have shown variations in the embryonic recovery rate of: 50.9 and $59.5 \%$ (Fleury et al. 2001), $63.4 \%$ in 658 collections (Jacob et al. 2002), and 60\% (Gusmão et al. 2010). The stress caused in T. equi carriers animals with disease clinical signs and treated with imidocarb dipropionate at therapeutic dose $(4 \mathrm{mg} / \mathrm{kg}$, q72h, in four applications) has caused great reduction in the embryonic recovery rate. Besides, this parasiticide is related to episodes of cramps, salivation, irritability, gastrointestinal hyper-motility, renal and liver failure, etc. However, using prophylactic doses $(1.2 \mathrm{mg} / \mathrm{kg})$ in chronic carrier mares, no undesirable side effects were observed, as well as, there was no decrease in the embryonic recovery rate and ges- 
tation rate according to what was reported in the present study.

Several factors directly influence the gestation rate in a ET, among the most important are the ones related to the embryo receptor (handling and selection), the quality of the embryo, day of inovulation, and the technical factor. Comercial ET programs in Brazil have present critical and experienced professionals for the "Mangalarga Marchador" breed (Jacob et al. 2002, 2010, Gomes et al. 2004); these programs have demonstrated the transcervical transfer method presenting gestation rates around 70\% according to the reported data, Rocha et al. (2007) assessing six reproductive seasons obtained a general average for 15 days of gestation of $73.4 \%$. Evaluating the pregnancy rate and early embryonic loss of "Mangalarga Marchador" mares in a non-surgical commercial ET program during six reproductive seasons, the same authors obtained rates of 69.9 and 4.8\%; 66.7 and 9.0\%; and 64.5 and $12.2 \%$ at 30, 45 and 60 days of gestation, respectively. The gestation rates of the present study corroborate to the findings previously reported, although none of these earlier studies accessed the infection by $T$. equi in the animals correlating it with gestation rates. In the present study, the gestation rates obtained were better after imidocarb dipropionate treatment, however, there was no significative difference ( $p>0.05)$.

During the mating season, most of the obtained receptors have presented the lowest cost at the moment of acquisition due to their low body score and high infestation by ectoparasites, nevertheless, feeding improvement , vermifugation and anti-tick baths have been enough to solve the animals physical conditions problems, however, it has been neglected that animals may be T. equi chronic carriers and the treatment with prophylactic dose $(1.2 \mathrm{mg} /$ $\mathrm{kg}$ ) might improve the results obtained at the end of mating season.

In literature no similar work has been described in the relation between embryonic quality and imidocarb dipropionate treated animals. It is known that after animals prophylactic treatment, there is a reduction on the parasitism in the blood stream, thus, avoiding the occurrence of anemia and feverish peaks in carrier animals, which can directly influence the embryo recovery rates, embryonic absorption, gestation rates and embryonic death in several ET programs. In a study, the increase of internal temperature in $2^{\circ} \mathrm{C}$, produced by 30 minutes of induced exercise, caused a decrease in embryonic recovery rate (from 63 to $34 \%$ ), in the embryos quality (from 73 to $36 \%$ grade I), in the size of ovulatory follicles and induced a delay in the return of the oestrus period for approximately seven days after prostaglandin administration (Mortensen 2009), demonstrating that the stress and elevation of temperatures in donor mares, also observed in theileriosis, can affect the dynamic of the estrous clycle.

\section{CONCLUSIONS}

It can be concluded that treatment with imidocarb dipropionate did not cause a significant improvement $(p>0.05)$ in the embryonic recovery rates and gestation rates at $15,30,45$ and 60 days.
However, there were important increases of $11.54 \%$ in the embryonic recovery rate, $15 \%$ in the gestation rate at 15 days and $10 \%$ in the gestation rate at 30, 45 and 60 days in the group treated with imidocarb dipropionate in relation to the untreated group.

The treatment of Theileria equi infection with imidocarb dipropionate raised the quantity of collected grade I embryos.

Acknowledgements.- This research was granted by the National Council for Scientific and Technological Development (CNPq), and Carlos Chagas Filho Foundation for Research Support of Rio de Janeiro State (FAPERJ). We also would like to appreciate Coordination for the Improvement of Higher Education Personnel (CAPES) for providing MSc scholarships to Luciana L. Bezerra.

\section{REFERENCES}

Allsopp M.T.E.P., Lewis B.D. \& Penzhorn B.L. 2007. Molecular evidence for transplacental transmission of Theileria equi from carrier mares to their apparently healthy foals. Vet. Parasitol. 48:130-136.

Baldani C.D. 2004. Estudo comparativo de técnicas diretas (esfregaço sanguíneo, cultivo in vitro e reação em cadeia polimerase) e indiretas (reação de imunofluorescência, ensaio imunoenzimático e fixação de complemento) no diagnóstico de Babesia equi em equinos naturalmente infectados. Tese de Doutorado, Faculdade de Ciências Agrárias e Veterinária, Universidade Estadual Paulista, Jaboticabal, SP. 93p.

Bruning A. 1996. Equine piroplasmosis: an update on diagnosis, treatment and prevention. Brit. Vet. J. 152:139-151.

Du Plessis J.L. \& Basson P.A. 1966. Babesiosis in aborted equine fetuses: a report on two cases in South Africa. J. Am. Vet. Med. Assoc. 37:267-269.

Fleury J.J., Pinto A.J., Marques A., Lima C.G. \& Arruda R.P. 2001. Fatores que afetam a recuperação embrionária e os índices de prenhez após transferência transcervical em eqüinos da raça Mangalarga. Braz. J. Vet. Res. Anim. Sci. 38:29-33.

Friedhoff K.T., Tenter A.M. \& Muller I. 1990. Haemoparasites of equines: impact on international trade of horses. Rev. Sci. Tech. Off. Int. Epiz. 9:1187-1194.

Gomes G.M., Jacob J.C.F. \& Domingues I.B. 2004. Utilization of mares after post partum uvulation as embryo recipients. 6th International Symposium on Equine Embryo Transfer, Rio de Janeiro, RJ, p.12. (Abstrac)

Gusmão A.L., Feitosa T.A.L., Moura J.C.A., Resende M.V., Martins L.E.P.M. \& Barbosa L.P. 2010. Recycling of catheter for embryo recovery: a tool for costs Reduction in equine embryo transfer. Ciênc. Anim. Bras. 11:425428.

Hailat N.Q., Lafi S.Q., Al-Darraji A.M. \& Al-Ani F.K. 1997. Equine babesiosis associated with strenuous exercise: clinical and pathological studies in Jordan. Vet. Parasitol. 69:1-8.

Jacob J.C.F., Domingues I.B., Gastal E.L., Gastal M.O., Silva A.G., Mello C.M. \& Gasparetto F. 2002. The impact of degree of synchrony between donors and recipients in a commercial equine embryo transfer program. Theriogenology 57:545.

Jacob J.C.F., Bezerra L.L., Santos H.A., Silva P.C.A. \& Massard C.L. 2010. Inquérito Epidemiológico pelo Nested-PCR para Detecção de Babesia equi em um Programa de Transferência de Embrião. XXIV Reunião Anual da Sociedade Brasileira de Tecnologia de Embriões, Porto de Galinhas. Acta Scient. Vet. 38:379.

Mortensen C.J., Choi Y.H., Hinrichs K., Ing N.H., Kraemer D.C., Vogelsang S.G. \& Vogelsang M.M. 2009. Embryo recovery from exercised mares. Anim. Rep. Sci. 110:237-244.

Nicolaiewsky T.B., Richter M.F., Lunge V.R., Cunha C.W., Delagostin O., Ikuta N., Fonseca A.S., Silva S.S. \& Ozaki L.S. 2001. Detection of Babesia equi (Laveran, 1901) by nested polymerase chain reaction. Vet. Parasitol. 101:9-21.

NRC 2007. Nutrients Requeriments of Horses. National Research Council, Washington, DC. 
Rampersad J., Cesar E., Campbell M.D., Samlal M. \& Ammons D. 2003. A field evaluation of PCR for the routine detection of Babesia equi in horses. Vet. Parasitol. 114:81-87.

Rocha A.N., Lopes E.P., Guimarães J.D., Siqueira J.B., Torres C.A.A., Pinho R.O. \& Carvalho G.R. 2007. Pregnancy rates and early embryo loss in a commercial embryo transfer program in Mangalarga Marchador mares. Anais 17ํㅡㄹ Congresso Brasileiro de Reprodução Animal, Curitiba, PR, p.160. (Abstract)

Sampaio I.B.M. 2002. Estatística Aplicada à Experimentação Animal. 2a ed. Fundação de Estudo e Pesquisa em Medicina Veterinária e Zootecnia, Belo Horizonte. 265p.
Santos T.M., Santos H.A. \& Massard C.L. 2008. Diagnóstico molecular de babesia congênita em potros neonatos no estado do Rio de Janeiro, Brasil. Revta Bras. Parasitol. 17:348-350.

Schein E. 1988. Equine babesioses, p.197-208. In: Ristic M. (Ed.), Babesiosis of Domestic Animals and Man. CRS Press, Boca Raton.

Simpson C.F. \& Neal F.C. 1980. Ultrastructure of Babesia equi in ponies treated with imidocarb. Am. J. Vet. Res. 41:267-271.

Squires E.L., McCue P.M. \& Vanderwal D.K. 1999. The current status of equine embryo transfer. Theriogenology 51:91-104.

Squires E.L., Carnevale E.M., McCue P.M. \& Bruemmer J.E. 2003. Embryo technologies in the horse. Theriogenology 59:151-170. 